\title{
The motivation to study of the student in security sciences and forensic sciences
}

\section{La motivación al estudio del estudiante en ciencias de la seguridad y ciencias forenses}

\author{
LUCIO, Rodolfo’ \& SESENTO, Leticia”' \\ Universidad Michoacana de San Nicolás de Hidalgo, Faculty of Veterinary Medicine and Zootechnics, Mexico. \\ "Colegio Primitivo y Nacional de San Nicolás de Hidalgo, Mexico.
} ID $1^{\text {st }}$ Author: Rodolfo, Lucio / ORC ID: 0000-0002-0535-3652, Researcher ID Thomson: X-2391-2018, CVU CONACYT
ID: 947303

ID $1^{\text {st }}$ Coauthor: Leticia, Sesento / ORC ID: 0000-0002-6456058X, Researcher ID Thomson: S-6997-2018, CVU CONACYT ID: 449302

DOI: $10.35429 /$ JTER.2020.18.6.1.7

Received July 10, 2020; Accepted December 30, 2020

\begin{abstract}
Motivation has been indicated as the engine for the success or failure of learning processes, although its origin continues to be a topic of permanent discussion. The objective of the present work was to know the level of motivation to study in the students of the Bachelor of Science in Security of the UMSNH. The applied methodology was quantitative and correlational with a non-experimental design. The instrument used was the Educational Motivation Scale (EME). The results show, the main intrinsic school motivations are: "I find satisfaction and I like to learn new things", followed by "I like to see that I surpass myself" and finally "it will allow me to choose a job in the branch that I like. ". Based on the extrinsic motivations they are: "to lead a comfortable life later", "because education better prepares me to pursue a career later" and finally "Why do I think that more years of studies increase my professional preparation". Teachers have a decisive role to provide confidence to the student, be empathetic and be in constant training that allows us to teach motivating classes for our students.
\end{abstract}

\section{Motivation, University, Intrinsic, Extrinsic}

\begin{abstract}
Resumen
La motivación ha sido señalada como el motor para el éxito o el fracaso de los procesos de aprendizaje, aunque su origen sigue siendo un tema de discusión permanente. El objetivo del presente trabajo fue conocer el nivel de motivación al estudio en los estudiantes de la Licenciatura en Ciencias de la Seguridad de la UMSNH. La metodología aplicada fue cuantitativa y correlacional con un diseño no experimental. El instrumento que se utilizo fue la Escala de Motivación Educativa (EME). Los resultados muestran, las principales motivaciones escolares intrínsecas son: "encuentro satisfacción y me gusta aprender cosas nuevas", seguido de "me agrada ver que me supero a mí mismo" y por último "me permitirá escoger un trabajo en la rama que me guste". En función a las motivaciones extrínsecas son: "llevar una vida cómoda más adelante", "porque la educación me prepara mejor para hacer una carrera después" y por último "Por qué creo que más años de estudios aumentan mi preparación profesional". Los docentes tienen un rol determinante para brindarle confianza al alumno, ser empáticos y estar en constante capacitación que permita impartir clases motivadoras para nuestros alumnos.
\end{abstract}

Motivación, Universitarios, Intrínseca, Extrínseca

Citation: LUCIO, Rodolfo \& SESENTO, Leticia. The motivation to study of the student in security sciences and forensic sciences. Journal of Teaching and Educational Research. 2020. 6-18:1-7.

\footnotetext{
* Correspondence to the Author (Email: dr.rlucio@ hotmail.com)

$\dagger$ Researcher contributing as first author.
} 


\section{Introduction}

School motivation reaches a special care since the role of the teacher in the XXI century will be increasingly complex; It is important to recognize that we all need to be motivated to live. When we transfer this natural need to formal environments and contents of institutionalized education, the motivation to learn is not always specified or shown with intensity. Everyone is concerned with knowing cases of more or less motivated students or more motivated students at some moments than others.

It has been recorded that motivational processes have a precise influence on successful school performance and on the initiative to promote learning that consolidate lasting motives, establishing interests and values that lead students to reflection and autonomous development (Aebli, 1991).

Motivation has been recognized as the engine for the success or failure of learning methods, however, its principle continues to have an argument for permanent discussion. In the special case of university students, who have chosen a career that they will practice during their existence, the argument between the supposed will to learn and the limited usefulness of doing so is even more surprising.

School dropout is a social educational problem, which is showing more and more incidence in Higher Level Institutions. For this reason, it is intended to know the level of motivation to study presented by upper-level students of the Security Sciences and Forensic Sciences career.

It has been established that motivational methods assume substantial dominance in successful school performance and in the disposition to attenuate learning that strengthens lasting motives, forming benefits and values that move students to reflection and free progress (Aebli, 1991).

Numerous authors have ventured into the definition of motivation towards university studies.
Motivation, according to Valle et al. (1997) is what causes an individual to decide to pursue university studies and stay in the classroom and is given by the pursuit of certain academic and personal goals. Motivation means movement towards the achievement of goals, and according to González (2005) this movement is conditioned by attitudes, which he defines as the capacities to respond favorably or not to certain stimuli, in this case related to learning, success academic and acceptance by teachers and fellow students.

Educators have to reflect on their process of teaching motivation; conceive that, if their students are not motivated, it would probably be one of the sources of school failure; so much so that motivation clearly influences learning; That is why it is one of the main objectives of teachers to motivate their students, since their success or frustration in university classes depends on that (Polanco, 2005).

From a historical approach, Abarca (1995), shows motivation as a phenomenon developed by several elements, which are manifested and absent according to the articulation determined by economic, social and cultural phenomena, for which, it concerns relate specifically to each of the subjects.

\section{Development}

It is important for the university student to be motivated, when the benefit of their learning is provided in the contour of knowledge, since the learning achieved provides them with extension in their designated profession and gives them one more step in the goal to achieve the academic end. (Polanco, 2005). A motivated student is a scholar who manifests constancy in the benefit of her career or when carrying out her university task. It is essential that the student is motivated to learn and a teacher who loves his subject, with excellent tools to teach it (Rinaudo, de la Barrera \& Donolo, 1997). However, the situation of being motivated or not to learn significantly not only rests largely on the will of the students, but also in an indisputable part by the authority of the environment that surrounds them. It is essential to point out that the school context and the teacher have an essential role in motivation, therefore, the necessary measures must be considered to consolidate the management of the aspects that manage to specify the motivational fabric of the student's action.

LUCIO, Rodolfo \& SESENTO, Leticia. The motivation to study of the student in security sciences and forensic sciences. Journal of Teaching and Educational Research. 2020 
Motivation is considered as the level that students have to strive to achieve academic goals.

For some teachers, motivation is appreciated as the level at which students work to achieve academic goals that they see as beneficial and meaningful. From the perspective of the teacher, it means motivating the student to do something, through promotion and awareness (Campanario, 2002). Motivating means inclining the student to actively participate in class commitments. The purpose of motivation is to move profit and control energies to achieve certain goals.

\section{Characteristics of low motivation}

Low motivation generates, in the first place, a state of anxiety, which has been evaluated by Rinaudo et al. (2003). The cause of this concern lies in the fact that students consider themselves poorly prepared for their academic performance, and it is a manifestation that has been scarcely studied since it is found on a psychological level, so it is not easy to quantify. Instead, one of the easily recognizable traits in poorly motivated students is absenteeism. Camargo (2010) notes the causes that originate absenteeism, and it is interesting that many of them can be attributed to the role of the teacher, and corrected with motivational actions:

The methodological preparation of the subject does not correspond to the proposed objective; activities are not aimed at achieving goals; the classes are monotonous and boring for lack of the presentation of concrete cases that conform to the theory seen; there is no appropriate tone of voice from the teacher, which prevents students from being distracted; the time the subject is taught is not appropriate.

There is no credibility in the teacher's abilities; he does not inspire respect or authority and his behavior is fearful, or he has no experience in managing groups, he has doubts in what he expresses; does not use an adequate teaching methodology and does not adequately prepare the classes; the explanations to the questions posed by the students are confusing and unsatisfactory.
- The teacher lacks an open and participatory method of presentation; does not give the student the opportunity to honestly express the reasons for their disagreement and lack of interest; it does not determine states of satisfaction among students; the student shows fear towards the teacher because of the way he directs academic practice; there are harsh criticisms of the teacher towards the student, who ridicule the latter.

- The excess of confidence between the teacher and the student makes the latter attend when he pleases; there are no levels of demand on the part of educators; the teacher constitutes a bad example because of his lateness or absence.

- Students are pressured to achieve the objectives established in some subjects, presenting excessive drasticity in teaching practice; the student obtains negative results and rejects the subject and the teacher.

- $\quad$ The student fixes the idea that the subject he is attending is not of great importance and suffers from an excess of confidence to pass it.

Other students with poor motivation do not adopt absenteeism as behavior; however, they show apathetic behavior: they remain silent in the activities, they refuse to answer questions or they try not to be designated to answer them, they do not deliver the assigned tasks on time. This type of behavior is fully conscious, and aims to avoid group rejection (Polanco, 2005). For what has been called avoidance.

The avoidance strategies that students develop have been analyzed by Hayamizu and Weiner (1991) and have as a common denominator the distrust of the negative judgments of teachers and classmates (Rodríguez et al., 2001). Faced with a motivational stage that forms tension, the avoidance of the unpleasant scenario is sought, and the affected person engages in explicit work and tendencies to reduce tension. In the best of cases, students are more anxious to pass than to learn (Míguez, 2005). 
Avoidance is grouped with a negative pattern of motivational beliefs (Urdan and Schoenfelder, 2006; Gámez et al., 2008). The ordinary propensity of this type of student, in the long term, is the abandonment of the race, but at this end it is reached by the path of learning problems.

\section{Types of motivation}

Intrinsic: intrinsic motivation is based on internal factors such as self-determination, curiosity, challenge, and effort, which emerge spontaneously due to internal tendencies and psychological needs that promote behavior without any extrinsic rewards (Reeve, 1994). Thus, intrinsic motivation will decrease if own feelings of competence and self-determination are reduced, which leads to two types of intrinsically motivated behavior, one occurs when the person is comfortable but bored and therefore motivated to find stimulation, and the another involves mastering challenges (Good and Brophy).

The cognitive approach to motivation emphasizes the intrinsic principles of motivation, such as research, profit for the job itself, a taste for learning, and a recognition of success. In other words, intrinsic motivation is that motivation associated with activities that are in themselves their own reward. Therefore, the student would prefer a career based on the aspiration to learn, by a recognition of firm success in knowledge, etc., is guided by internal rewards. Finally, humanistic approaches to motivation emphasize self-independence, autonomy, and particular effort, the theory emphasizes intrinsic motivation. One of the most notorious authors of the approach is Abraham Maslow who has enjoyed formidable recognition in motivational psychology. Specifically, he proposed that human needs are hierarchical and that they tend to be satisfied according to their order. (Fadiman and Franger, 1979 p, 355-356).

Extrinsic motivation: this changes in relation to the autonomy that the subject has, categorized from less to more self-determined, which allows making a distinction between external, introjected, identified and integrated (León, 2010). Therefore, a person is extrinsically motivated towards an activity when there is a benefit from it.

\section{Methodology}

To know the level of motivation to study in students of the Bachelor of Science in Security of the UMSNH. A mixed methodology with a qualitative and correlational inclination was used with a non-experimental design. The instrument used is the Educational Motivation Scale (EME), which is a quantitative technique that is made up of 28 items distributed from 4 items that evaluate the 3 types of intrinsic motivation (MI) to knowledge, achievement and experiences stimulatory, 3 types of extrinsic motivation (EM) external regulation introjected regulation, identified regulation and motivation. For the application of the instrument, a nonprobability sampling was applied to 149 students. The systematization of the information consisted in the elaboration of frequency tables to identify the needs to work in the coordination of tutorials.

In the data analysis, the intrinsic motivation of the students is predominantly observed, as shown in the following graph the main intrinsic school motivations are: "I find satisfaction and I like to learn new things", followed by "I like to see that I improve myself "and finally" it will allow me to choose a job in the branch that I like".

\section{INTRINSIC MOTIVATION}

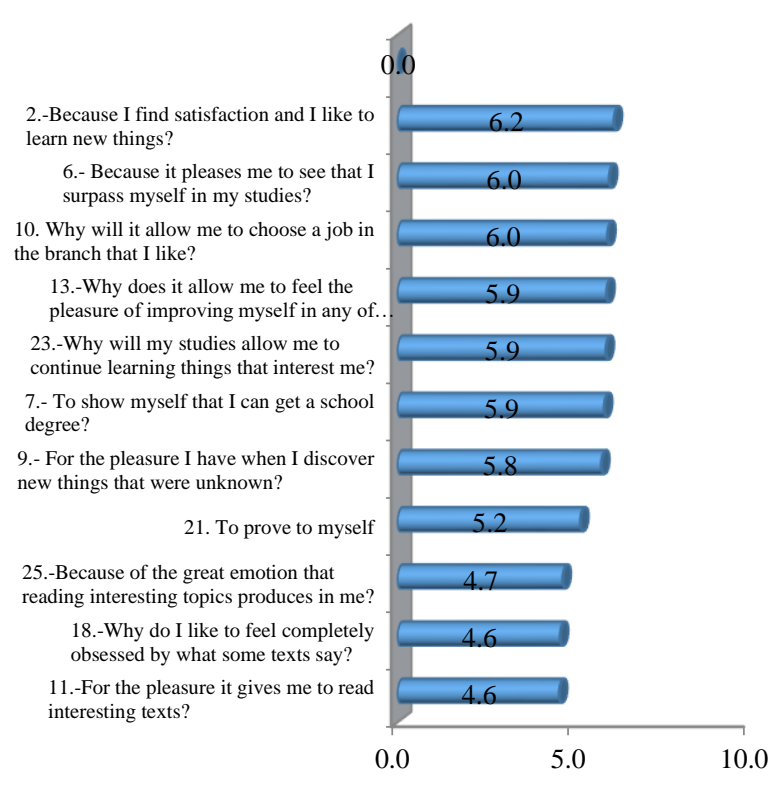

Graphic 1 
On the other hand, based on extrinsic motivations, according to the data we can highlight that the three main ones are; "Lead a comfortable life later", followed by "because education prepares me better for a career later" and finally "Why do I think that more years of studies increase my professional preparation".

\section{Extrinsic motivation}

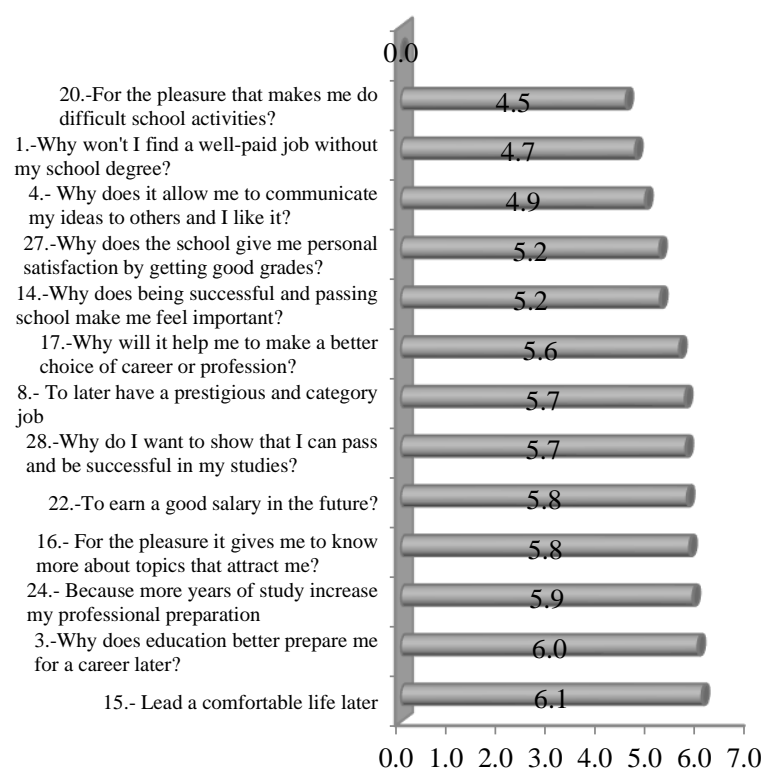

\section{Graphic 2}

Regarding non-motivating behaviors in young people, the perspective of "before I was encouraged, but now I don't know if I should continue" stands out, followed by "honestly, I have the feeling of wasting my time here".

Non-motivating behaviors

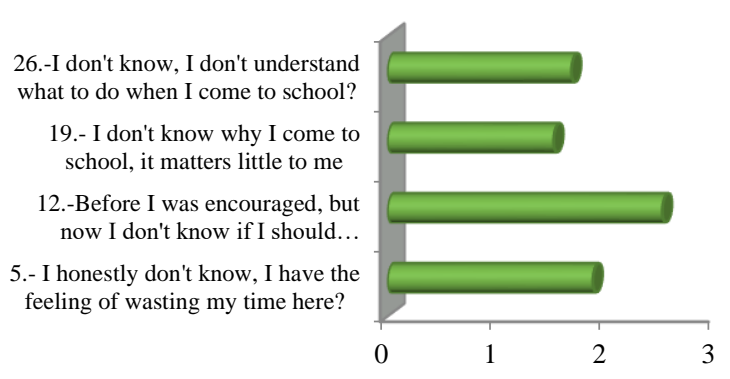

Graphic 3

\section{Results}

The intrinsic motivation of the students, the main intrinsic school motivations are: "I find satisfaction and I like to learn new things", followed by "I am pleased to see that I surpass myself" and finally "it will allow me to choose a job in the field that I like".
Therefore, there is an area of opportunity for teachers of this career that corresponds to be used by teachers and the appropriate option would be the application of active strategies.

In terms of extrinsic motivations, according to the data we can highlight that the three main ones are; "Lead a comfortable life later", followed by "because education better prepares me for a career later" and finally "Why I think that more years of studies increase my professional preparation." To enhance this type of motivation, teachers have a decisive role as they must provide confidence to the student, be empathetic and be in constant training that allows motivating classes for students; It is essential to include educational resources with which students are familiar in the classroom.

Regarding non-motivating behaviors in young people, the perspective of "before I was encouraged, but now I don't know if I should continue" stands out, followed by "honestly, I have the feeling of wasting my time here". It is essential that the coordination of tutorials work with the students who present this type of answers since they will be the ones who possibly abandon the degree.

\section{Discussion}

Most of the surveyed students report a high level of motivation and self-efficacy beliefs; They are distinguished capable and competent to solve actions that are posed to them, possibly, a greater assignment to tasks and cognitive responsibility will help them to have better achievements (Huertas, 1997). The university teacher is challenged at this time to an atmosphere of change that demands to take a different role (Rodríguez, 2002); It not only belongs to him to be a scholar in his field, an expert in methodologies and, but he demands to be a guide and reviewer of the student's intellectual formation. It is essential to transform the traditional role of teachers to a role of transmitter of knowledge, to achieve the role of organizer and guide of learning, facilitator who prepares contexts, originates, locates on methods, shows basic research, raises databases for consultations, tutelage and appreciate the preparation of exercises (Álvarez and García, 2002; González and Wagenaar, 2003). 
In university tutoring it is recognized as a dynamic connection point of the academic, specific and professional pedagogical matter of the student, focused on forming entrepreneurial students who know and manage to organize their adequate work as students and future independent professionals.

The pedagogical support is essential to form this knowledge, since it is presumed that they do not develop spontaneously (Vélez, 1999). Thus, the need to teach how to use learning strategies is proposed, since, however, students also learn, despite the fact that they are not taught, the fact of doing so manages to benefit quality learning. Burón (1996) argues that it would be appropriate to provide a 'turn in instruction', so that it not only lies in teaching disciplinary content, but also offers to teach students to develop effective learning strategies.

The university professor is forced by a combination of tasks inherent to his function and, at this moment, it seems utopian to reconsider that complying with all of them requires time and effort to dedicate to rethinking about how to help in aspects such as motivation and the use of learning strategies by students. The instructional effort required by this approach is considerable, but the favorable theoretical foundations and the favorable results that are stored in research exploited in the educational field stimulate to prolong the energies in this sense (Vélez, 1999). Furthermore, we conceive that it is not a question of worrying about perfect teaching or expecting teachers to be perfect. In their context, they would have to work towards excellent teaching, one that enjoys the motivations and thoughts of others, and that provides significant experiences and achievements both from an emotional, professional and cognitive point of view.

\section{Conclusions}

It is essential to know the level of motivation to study in the students of the Bachelor of Science in Security of the UMSNH, so that the coordination of tutorials can work with them, the type of motivation in which they are low and raise awareness among teachers so that they assume a precise role since it is important to give confidence to the student, to be empathetic and to be in constant training that allows sharing motivational classes for students.
This can be, as a simple example, the incorporation of the use of social networks, applications, websites, subject web, among other technological educational resources. To maintain the interest of the student, the natural energy of the student must be harnessed to appreciate herself capable and oriented towards the achievement of goals. It is necessary that you do voluntarily what you are expected to do; and develop your skills to achieve the desired goal. Thus, the more capable a student feels to develop an activity, the more motivated he will be to persist in it, in turn, it will give him the feeling of success or improvement and help him stay motivated. The teacher must bear in mind that the student needs the possibility of exploring options; receive positive feedback on your strengths and weaknesses.

\section{References}

Abarca, S. (1995). Psicología de la motivación. San José, C.R.: Editorial Universidad Estatal a Distancia

Aebli, H. (1991). Factores de la Enseñanza que Favorecen el Aprendizaje Autónomo. Madrid: Ed. Narcea, p. 113-143.

Álvarez, V. y García, E. (2002). Orientación del aprendizaje en la enseñanza universitaria. En V. Álvarez Rojo, y A. Lázaro Martínez (Coords.), Calidad de las universidades y orientación educativa (pp. 215-247). Málaga: Aljibe.

Burón, J. (1994). Motivación y aprendizaje. Bilbao: Mensajero. Burón J. (1996). Enseñar a aprender. Introducción a la metacognición. Bilbao: Mensajero.

Camargo, D. (2010). Código de ética del estudiante universitario. Disponible en: http://www.eumed.net/librosgratis/2010c/721/index.htm.

Campanario, J. M. (2002). ¿Cómo influye la motivación en el aprendizaje de las ciencias?. Disponible:///C:/Users/letic/Downloa ds/21572-Texto\%20del\% 20art\%C3\%ADculo21496-1-10-20060309\%20(1).pdf

Gámez, E.; Marrero, H. y Díaz, J. M. (2008). Motivación interpersonal y metas vitales en estudiantes universitarios. Disponible en: https:/dialnet.unirioja.es/servlet/articulo?codig $\mathrm{o}=4612677$. 
González, I. (2005). Motivación y actitudes del alumnado universitario al inicio de la carrera. ¿Varían al egresar? Revista Electrónica de Investigación Psicoeducativa y Psicopedagógica No. 5-3 (1) Pág. 35-56.

Good, T. y Brophy, J. (1996). Psicología Educativa Contemporánea. México, D.F.: McGraw-Hill.

Fadiman, J, y Franger, R. (1979). Teorías de la Personalidad. México: Ed. Harla, p. 355-356.

Hayamizu, T., y Weiner, B. (1991). A test of Dweck's model of achievement goals as related to perceptions of ability. The Journal of Experimental Education 59 Pág. 226- 234.

Huertas, J.A. (1997). Motivación. Querer aprender. Buenos Aires: Aique

León, J. (2010). Inteligencia emocional y motivación en el deporte. Tesis doctoral: Universidad de las Palmas de Gran Canaria.

Míguez, M. (2005). El núcleo de una estrategia didáctica universitaria: motivación y comprensión. Revista Electrónica de la Red de Investigación Educativa [en línea]. Vol.1, No.3: 1-11.

Disponible en:http://revista.iered.org/v1n3/pdf/mmiguez.pd f

Polanco, A. (2005). La motivación en los estudiantes universitarios. En Revista Electrónica Actualidades investigativas en educación, 5(2), 1-13. Disponible en: https://www.redalyc.org/pdf/447/44750219.pdf.

Reeve, J. (1994). Motivación y Emoción. Disponible https://www.redalyc.org/pdf/1471/1471181100 15.pdf

Rinaudo, M.; Chiecher, A. y Donolo, D. (2003). Motivación y uso de estrategias en estudiantes universitarios. Disponible: https://www.um.es/analesps/v19/v19_1/1119_1.pdf.

Rodríguez, G. (2002). El reto de enseñar hoy en la Universidad. En V. Álvarez y A. Lázaro (Coods.), Calidad de las universidades y orientación universitaria (pp. 49-58). Málaga: Aljibe.
Rodríguez, S., Cabanach, R.; Piñeiro, I.; Valle, A.; Núñez, C. y González, J. (2001). Metas de aproximación, metas de evitación y múltiples metas académicas. Disponible: http://www.psicothema.com/pdf/477.pdf.

Rinaudo, M.C., Donolo, D. y Chiecher, A. (1997). Los procesos de solicitar, dar y recibir ayuda pedagógica. Cronía, Revista de Investigación de la Facultad de Ciencias Humanas., 3 (1), 60-70.

Urdan, T., y Schoenfelder, E. (2006). Classroom effects on student motivation: Goal structures, social relationships, and competence beliefs. Journal of School Psychology 44 pág. 331-349.

Skaalvik, E.M. y Skaalvik, S. (2007). Dimensions of teacher self-efficacy and relations with strain factors, perceived collective teacher efficacy, and teacher burnout. Journal of Educational Psychology, 99, 611-625.

Valle, A.; González, R. y Cuevas, R. (1997). Patrones motivacionales en estudiantes universitarios: características diferenciales. Revista de Integración Educativa 15 (1) Pág. 125-146.

Vélez, G. (1999). Aprender a estudiar ¿una cuestión de técnicas?.Contextos de Educación, Año I, 2, 134-149.

Wolters, C.A. y Daugherty, S.G. (2007). Goals structures and teachers' sense of efficacy: Their relation and association to teaching experience and academic level. Journal of Educational Psychology, 99, 181-193. 